2020, Volume 14, International Conference Innovative Business Management \& Global Entrepreneurship (IBMAGE 2020), pages: 594-610 | https://doi.org/10.18662/lumproc/ibmage2020/43

\section{Social Inequality and Solutions to Sustainable Development in the European Union}

\section{Paula MUNTEANU1, Laurenţiu CIORNEI²}

\footnotetext{
${ }^{1}$ School of Advanced Studies of the Romanian Academy (SCOSAAR), Romanian Academy, Bucharest, Romania, pma.munteanu@gmail.com
}

${ }^{2}$ Center for Study and Research for AgroForestry Biodiversity "Acad. David Davidescu", Romanian Academy, Bucharest, Romania, laurentiu.ciornei@ince.ro
Abstract: Although the process of accession to the European Union supposed the fulfillment of certain conditions, called the "Coopenhagen Criteria", although there were economic, social and cultural differences, the fact that accession was based on democratic impulses determined development to evolve differently. Differences between countries have intensified over time, being determined by the fact that not all EU countries are in the Eurozone or in the Schengen area.

Romania has not been able to raise the living standards of its citizens since its accession to the European Union. Although the number of employed people has increased, one-fifth of them remain poor. This shows that the measures taken so far have not been effective or sustainable.

In order to understand the effects on sustainable development that Romania could fully feel in this difficult period that the world is going through as a result of the pandemic generated by Covid-19, in this analysis we considered the global assessment of social disparities in conjunction with the particularities of the "multi-speed" European Union.

Results show that Romania is struggling with a social situation inferior to the Member States, and, without concrete measures to recover and counteract, social inequality will continue to deepen.

Keywords: Sustainable development; labor force; social inequality.

How to cite: Munteanu, P., \& Ciornei, L. (2020). Social Inequality and Solutions to Sustainable Development in the European Union. In M. W. Staniewski, V. Vasile, \& A. Grigorescu (vol. eds.), Lumen Proceedings: Vol. 14. International Conference Innovative Business Management \& Global Entrepreneurship (IBMAGE 2020) (pp. 594-610). Iasi, Romania: LUMEN Publishing House. https://doi.org/10.18662/lumproc/ibmage2020/43 


\section{Introduction}

More than half of the world's population continues to live below the poverty line, with one-fifth of the world's population living below the desperately threshld. Every day, almost 24,000 people die of hunger in the world while the number of millionaires increases. According to the Global Wealth Report [6], if in 2000 there were 13.9 million millionaires in USD worldwide (34\% of total global wealth), by mid-2019, they numbered 46.8 million, representing about $0.92 \%$ of the adult population of the globe $(44 \%$ of global wealth).

By 2024, the number of millionaires in USD is expected to increase to about 66 million, while the number of ultra high net worth individuals (UHNWI) is projected to reach 234,000 .

As it is known, the resources are limited and the increase of the number of multimillion persons determines the increase of the number of poor people, the wealth migrating from one side to the other.

Although the gap between rich and poor decreased in emerging markets, especially in China, the same trend it cannot be globally stated. In other words, with economic growth and the development of technologies on a global scale, social disparities have also increased, the percentage represented by the middle class remaining below $30 \%$.

"A system that creates widespread poverty is unethical." [5] If economic theories of past centuries have focused on profit sharing for employment and increasing the well-being of many people, the increase in the rich and very rich population of the last decade shows that profit distribution is oriented only to a certain segment, the distribution of wealth exceeding the principles of social equity. Or, equity is a key social concept when it comes to sustainable development.

Recent violence in the United States extended in the form of protests in Europe also highlights deep social inequities and inequalities, as well as institutionalized racism. In the United States, the recent coronavirus pandemic has primarily affected the unemployed and social security population, most of whom African Americans and Hispanics, have lost jobs, as a result of the new virus. According to data that has been made public, 23 percent of those who died in the pandemic were African-American, although their share is only 13 percent of the population.

Even in Europe, things are not different. Racism is alive and well, and the 2005 protests in France and Germany and the 2011 protests in the UK show that the scourge is also present in Europe, even less publicized. However, European inequity is not so much about racial differentiation, but 
rather about widespread differentiation between countries, according to the "multi-speed" concept and the differentiation within countries due to obvious social disparities.

\section{Problem Statement}

Of the 53 independent states that make up Europe (without taking into consideration the partially recognized states or the non-sovereign island states/states) only 27 countries are part of the European Union, given the exit of Great Britain produced on 31.01.2020. Of the $27 \mathrm{EU}$ countries, only 19 countries have adopted the single currency, the euro, being known generically as part of the Eurozone. The great achievement of Europe was the Schengen Area, being a collage of $26 \mathrm{EU}$ and non-EU countries, which do not yet include certain EU countries (Bulgaria, Croatia, Cyprus, Ireland and Romania) but in which non-EU countries have been incorporated (Iceland, Liechtenstein, Norway and Switzerland).

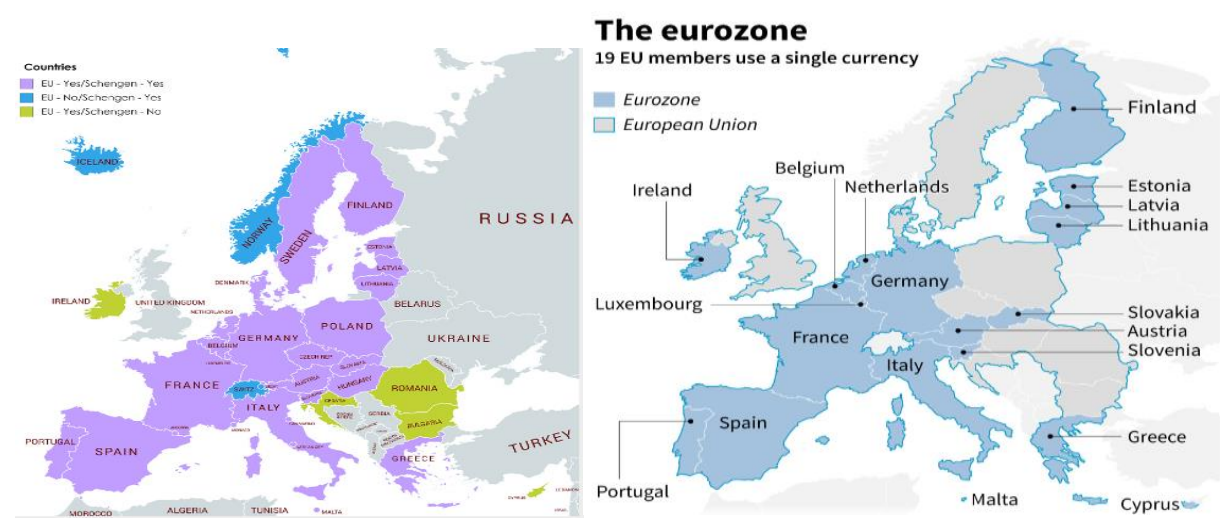

Figure 1. The Schengen Area (left) The eurozone (right). Source: Authors captures $[9,10]$

In other words, only $22 \mathrm{EU}$ Member States are in the Schengen Area, an area where business people and tourists can freely move without being subject to border controls.

Accession to the European Union began in 1951 when France, Germany, Belgium, Italy, Luxembourg and the Netherlands signed the first economic cooperation, the European Coal and Steel Community. The rest of the countries joined in seven subsequent stages, for 40 years, between 1973 and 2013, the largest expansion occurring in 2004, when most countries in the old communist bloc joined the union. 
Although the process of accession to the European Union supposed the fulfillment of certain conditions, called the "Coopenhagen Criteria", the fact that accession was based on democratic impulses, although there were economic, social and cultural differences, determined that the development to evolve differently. Differences between countries have been intensified over the time and are determined by the fact that not all EU countries are in the Eurozone or in the Schengen area.

Moreover, delay in adoption of some policies, especially by the countries located in Eastern Europe, has led to instability and the immigrant crisis and the imminence of Brexit, which has meanwhile taken place, have deepened the trends of differentiated development of Europe, especially in terms of economic (especially from a financial and fiscal perspective) and social, two of the basic pillars of sustainable development.

Thus, only 44 years after the first enlargement of the European Union, at the beginning of 2017, following the meeting at the Palace of Versailles between the leaders of the strongest EU states, the concept of a "multi-speed" Europe appeared. Six months later, Emmanual Macron resumed the idea in a speech at Sorbonne University in Paris, accepting the idea of creating several groups of member states, evolving at "different paces and speeds".

In the same year, on May 11, 2017, in the plenary of the Romanian Parliament, Jean-Claude Juncker stated that "In Europe there are no countries worth more than others, nations are equal (...) There have never been second hand countries.(...) Europe has been divided in the past, this must not happen again. We can move forward together, but at different paces. A Europe that has more speeds already exists, it is provided in the treaties (...)" [3].

However, a Europe with more speeds could generate more "Brexit" which would compromise the European Union unity, and the integration efforts of the last joined countries would have been in vain. The EU's principles of sustainable development must aim at the interconnection, at European level, between the three pillars: economic, social and environmental. Since 2004, the European Commission itself has argued that discussions on sustainable development without reference to the relationship between the three pillars are "artificial" and "false". [4]

Or, addressing a core of "avant-garde" countries that should lead to deeper integration of countries into the $\mathrm{EU}$, in the context of the principles of sustainable development, will compromise the achievement of this goal because this concept of sustainable development aims to achieve a balanced between the environmental, economic and social pillars, however, at European level. 
Moreover, given the shortening of global economic cycles (8-10 years) and the shocks that may occur, the sustainable development of the EU must be approached in a uniform and undifferentiated way. The European Union must deal with crises and shocks in the most predictable way possible. This means that cyclical recessions and shocks can be separated from those caused by internal causes, in order to avoid disasters. According to Nassim Nicolas Taleb, even rare events (of the black swan type), with major impact, can be predicted. Applying the principle of prevention and knowing the tolerance for risks can lead to avoiding risks and mitigating the effects.

Or, as it is know, in Europe "with more speed" the accumulation of wealth is uneven with disparities in the distribution of economic assets and income. The general quality of life is different between the countries of the European Union, access to housing, health services, income of a salary nature being differentiated as a result of the varied distribution of wealth.

Under these conditions, it can be said that in Europe "with more speed" there is both social inequality and economic inequality, which, although different, influence each other, being linked to each other.

\section{Research Questions/Aims of the research}

The main objective of the study is to anticipate the evolution that Romania can register in the next period, from the perspective of social inequality in Europe "with more speeds". We start from the hypothesis that Romania is going to fight with a social situation inferior to the member states, without concrete measures of recovery and counteracting, the social inequality will continue to deepen.

According to the Europe 2020 strategy, Romania intends to reduce by 580,000 people, the number of those at risk of poverty and social exclusion, by the end of 2020 . Achieving this target has aimed at constant increasing of the employment rate to a level of $70 \%$ and of the income, above the relative poverty line set in 2014 at the level of 600.4 RON. The strategy did not take into account either the differentiation between people in poverty or the estimated time period for keeping income above the poverty line. Or, as a phenomenon, poverty is much more complex than it seems at first glance. All factors that generate it must be taken into account, as well as social inequality, as a whole, by taking into account the highest and lowest incomes in Romanian society. Poverty stopping measures must be concrete and aim to increase the standard of living, not just indicators that ultimately say nothing. 


\section{Research Methods}

In order to achieve the main objective of the study, we performed a comparative analysis of several indicators, for period of time between 20102019, at the level of the member states of the European Union, taking into account some of the most representative indicators: the European employment rate, GINI Index and the evolution of the number of millionaires. We considered the analysis of several objectives included in the Europe 2020 strategy, a strategy in which European leaders aimed at reducing poverty and social inequalities for the period 2010-2020.

We continued the comparative study for Romania, taking into account the same indicators, the particular economic situation that Romania has and the forecasts for 2020 .

Based on the available data, we formulated conclusions regarding the evolution of the Romanian labor force. The hypothesis is confirmed that social inequality will continue to deepen given that the objectives of eradicating poverty and reducing inequality have not only not been achieved, but have been accentuated. Over these, the recent pandemic has come as an accelerator to the imminent collapse of the human resources.

\section{Findings}

Inequality means that financial resources are largely distributed to a small percentage of the population, the majority being affected. Inequality generates poverty and poverty affects health, education, school dropout and living conditions in general. These two phenomena that are interconnected and, together, influence economic development.

The social pillar broadly refers to public policies that support social issues. These social issues relate to our well-being and include issues such as health care, education, housing, employment, etc. They ensure that individuals have access to social services, do not suffer from a lack of knowledge of their rights and exert a responsible influence on development, policies and social services, both locally and nationally.

The Aalborg Charter states that policy must seek to "integrate people's basic social needs as well as environmental care, employment and housing programs" [7].

Through the Europe 2020 strategy, European leaders aimed to reduce poverty and social inequality for the period 2010-2020. This strategy aimed to achieve an average employment rate of $75 \%$, among other things, aimed at reducing the number of people living below the poverty line. Each EU member state has set its own target, with the target employment rate being between $62.9 \%$ in Croatia and $80 \%$ in several developed countries 
(Denmark, the Netherlands and Sweden). At the end of 2019, the employment rate at EU28 level was $73.9 \%$, being exceeded by a number of 20 countries while others still have to recover, and in the case of Greece, there was even a setback compared to the value recorded in 2010 (Table 1).

Table 1. The european employment rate $(\%)$

\begin{tabular}{|c|c|c|c|c|}
\hline & 2010 & 2019 & Target & $\begin{array}{l}\text { Degree of } \\
\text { objective } \\
\text { achievement } \\
\text { at 31.12.2019 }\end{array}$ \\
\hline EU28 & 68,5 & 73,9 & 75 & $99 \%$ \\
\hline EU27 & & & 75 & \\
\hline Belgium & 67,6 & 70,5 & 73,2 & $96 \%$ \\
\hline Bulgaria & 64,7 & 75 & 76 & $99 \%$ \\
\hline Czechia & 70,4 & 80,3 & 75 & $107 \%$ \\
\hline Denmark & 74,9 & 78,3 & 80 & $98 \%$ \\
\hline Germany & 75 & 80,6 & 77 & $105 \%$ \\
\hline Estonia & 66,8 & 80,2 & 76 & $106 \%$ \\
\hline Ireland & 65,5 & 75,1 & 69 & $109 \%$ \\
\hline Greece & 63,8 & 61,2 & 70 & $87 \%$ \\
\hline Spain & 62,8 & 68 & 74 & $92 \%$ \\
\hline France & 68,9 & 71,6 & 75 & $95 \%$ \\
\hline CroaTia & 62,1 & 66,7 & 62,9 & $106 \%$ \\
\hline Italy & 61 & 63,5 & 67 & $95 \%$ \\
\hline Cyprus & 75 & 75,7 & 75 & $101 \%$ \\
\hline Latvia & 64,3 & 77,4 & 73 & $106 \%$ \\
\hline Lithuania & 64,3 & 78,2 & 72,8 & $107 \%$ \\
\hline Luxembourg & 70,7 & 72,8 & 73 & $100 \%$ \\
\hline Hungary & 59,9 & 75,3 & 75 & $100 \%$ \\
\hline Malta & 60,1 & 77,2 & 70 & $110 \%$ \\
\hline Netherlands & 76,2 & 80,1 & 80 & $100 \%$ \\
\hline Austria & 73,9 & 76,8 & 77 & $100 \%$ \\
\hline Poland & 64,3 & 73 & 715 & $103 \%$ \\
\hline Portugal & 70,3 & 76,1 & 75 & $101 \%$ \\
\hline Romania & 64,8 & 70,9 & 70 & $101 \%$ \\
\hline Slovenia & 70,3 & 76,4 & 75 & $102 \%$ \\
\hline Slovakia & 64,6 & 73,4 & 72 & $102 \%$ \\
\hline Finland & 73 & 77,2 & 78 & $99 \%$ \\
\hline Sweden & 78,1 & 82,1 & 80 & $103 \%$ \\
\hline
\end{tabular}

Source: Processing of authors based on Eurostat data

The GINI indicator, was 30.8\% (available for 2018 for the EU28) up from 2010 (Table 2). It is noted that the countries of origin of European 
millionaires have seen increases in the GINI index, which confirms that as the number of people who have become rich has increased, in the meantime the number of people who have become poorer and inequalities have deepened. (Table 3).

Table 2. GINI Index, UE28, 2010-2018

\begin{tabular}{|c|c|c|c|c|c|c|c|c|c|}
\hline & 2010 & 2011 & 2012 & 2013 & 2014 & 2015 & 2016 & 2017 & 2018 \\
\hline UE28 & 30,5 & 30,8 & 30,5 & 30,5 & 31,0 & 31,0 & 30,8 & 30,6 & 30,8 \\
\hline UK & 32,9 & 33,0 & 31,3 & 30,2 & 31,6 & 32,4 & 31,5 & 33,1 & 33,5 \\
\hline Belgium & 26,6 & 26,3 & 26,5 & 25,9 & 25,9 & 26,2 & 26,3 & 26,1 & 25,7 \\
\hline Bulgaria & 33,2 & 35,0 & 33,6 & 35,4 & 35,4 & 37,0 & 37,7 & 40,2 & 39,6 \\
\hline Czechia & 24,9 & 25,2 & 24,9 & 24,6 & 25,1 & 25,0 & 25,1 & 24,5 & 24,0 \\
\hline Denmark & 26,9 & 26,6 & 26,5 & 26,8 & 27,7 & 27,4 & 27,7 & 27,6 & 27,8 \\
\hline Germany & 29,3 & 29,0 & 28,3 & 29,7 & 30,7 & 30,1 & 29,5 & 29,1 & 31,1 \\
\hline Estonia & 31,3 & 31,9 & 32,5 & 32,9 & 35,6 & 34,8 & 32,7 & 31,6 & 30,6 \\
\hline Ireland & 30,7 & 29,8 & 30,4 & 30,7 & 31,1 & 29,7 & 29,6 & 30,6 & 28,9 \\
\hline Greece & 32,9 & 33,5 & 34,3 & 34,4 & 34,5 & 34,2 & 34,3 & 33,4 & 32,3 \\
\hline Spain & 33,5 & 34,0 & 34,2 & 33,7 & 34,7 & 34,6 & 34,5 & 34,1 & 33,2 \\
\hline France & 29,8 & 30,8 & 30,5 & 30,1 & 29,2 & 29,2 & 29,3 & 28,8 & 28,5 \\
\hline Croatia & 31,6 & 31,2 & 30,9 & 30,9 & 30,2 & 30,4 & 29,8 & 29,9 & 29,7 \\
\hline Italy & 31,7 & 32,5 & 32,4 & 32,8 & 32,4 & 32,4 & 33,1 & 32,7 & 33,4 \\
\hline Cyprus & 30,1 & 29,2 & 31,0 & 32,4 & 34,8 & 33,6 & 32,1 & 30,8 & 29,1 \\
\hline Latvia & 35,9 & 35,1 & 35,7 & 35,2 & 35,5 & 35,4 & 34,5 & 34,5 & 35,6 \\
\hline Lithuania & 37,0 & 33,0 & 32,0 & 34,6 & 35,0 & 37,9 & 37,0 & 37,6 & 36,9 \\
\hline Luxembourg & 27,9 & 27,2 & 28,0 & 30,4 & 28,7 & 28,5 & 31,0 & 30,9 & 33,2 \\
\hline Hungary & 24,1 & 26,9 & 27,2 & 28,3 & 28,6 & 28,2 & 28,2 & 28,1 & 28,7 \\
\hline Malta & 28,6 & 27,2 & 27,1 & 28,0 & 27,7 & 28,1 & 28,6 & 28,2 & 28,7 \\
\hline Netherland & 25,5 & 25,8 & 25,4 & 25,1 & 26,2 & 26,7 & 26,9 & 27,1 & 27,4 \\
\hline Austria & 28,3 & 27,4 & 27,6 & 27,0 & 27,6 & 27,2 & 27,2 & 27,9 & 26,8 \\
\hline Poland & 31,1 & 31,1 & 30,9 & 30,7 & 30,8 & 30,6 & 29,8 & 29,2 & 27,8 \\
\hline Portugal & 33,7 & 34,2 & 34,5 & 34,2 & 34,5 & 34,0 & 33,9 & 33,5 & 32,1 \\
\hline Romania & 33,5 & 33,5 & 34,0 & 34,6 & 35,0 & 37,4 & 34,7 & 33,1 & 35,1 \\
\hline Slovenia & 23,8 & 23,8 & 23,7 & 24,4 & 25,0 & 24,5 & 24,4 & 23,7 & 23,4 \\
\hline Slovakia & 25,9 & 25,7 & 25,3 & 24,2 & 26,1 & 23,7 & 24,3 & 23,2 & 20,9 \\
\hline Finland & 25,4 & 25,8 & 25,9 & 25,4 & 25,6 & 25,2 & 25,4 & 25,3 & 25,9 \\
\hline Sweden & 25,5 & 26,0 & 26,0 & 26,0 & 26,9 & 26,7 & 27,6 & 28,0 & 27,0 \\
\hline
\end{tabular}

Source: Authors seletion based on Eurostat data, 2018 
It should be noted that three of the countries of origin of European millionaires (France, Spain and Belgium) have registered a positive evolution of the GINI index, that can be explained in terms of lower wealth accumulation, compared to other millionaires from the Netherlands, Germany and Italy, the countries with the largest depreciations of the GINI index. The increase in the number of millionaires in Netherlands can be explained by the fact that the Netherlands still "enjoys" the privilege of being in the top of the global ranking (4th place) of tax havens, due to preferential treatment of foreign investment, income tax and dividends.

Table 3. Comparisons - GINI Index and employment rate UE28, 20102018

\begin{tabular}{|c|c|c|c|c|c|c|}
\hline & $\begin{array}{c}201 \\
0\end{array}$ & $\begin{array}{c}201 \\
8\end{array}$ & $\begin{array}{c}\text { GINI } \\
\text { Evolution }\end{array}$ & $\begin{array}{c}201 \\
0\end{array}$ & $\begin{array}{c}201 \\
8\end{array}$ & $\begin{array}{l}\text { The employment } \\
\text { rate }\end{array}$ \\
\hline UE28 & 30,5 & 30,8 & 0,3 & 68,5 & 73,2 & 4,7 \\
\hline UK & 32,9 & 33,5 & 0,6 & 73,5 & 79 & 5,2 \\
\hline Belgium & 26,6 & 25,7 & $-0,9$ & 67,6 & 69,7 & 2,1 \\
\hline Bulgaria & 33,2 & 39,6 & 6,4 & 64,7 & 72,4 & 7,7 \\
\hline Czechia & 24,9 & 24,0 & $-0,9$ & 70,4 & 79,9 & 9,5 \\
\hline Denmark & 26,9 & 27,8 & 0,9 & 74,9 & 77,5 & 2,6 \\
\hline Germany & 29,3 & 31,1 & 1,8 & 75 & 80 & 4,9 \\
\hline Estonia & 31,3 & 30,6 & $-0,7$ & 66,8 & 79,5 & 12,7 \\
\hline Irleland & 30,7 & 28,9 & $-1,8$ & 65,5 & 74,1 & 8,6 \\
\hline Greece & 32,9 & 32,3 & $-0,6$ & 63,8 & 59,5 & $-4,3$ \\
\hline Spain & 33,5 & 33,2 & $-0,3$ & 62,8 & 67 & 4,2 \\
\hline France & 29,8 & 28,5 & $-1,3$ & 68,9 & 71,3 & 2,4 \\
\hline Croatia & 31,6 & 29,7 & $-1,9$ & 62,1 & 65,2 & 3,1 \\
\hline Italy & 31,7 & 33,4 & 1,7 & 61 & 63 & 2 \\
\hline Cyprus & 30,1 & 29,1 & $-1,0$ & 75 & 74 & $-1,1$ \\
\hline Latvia & 35,9 & 35,6 & $-0,3$ & 64,3 & 76,8 & 12,5 \\
\hline Lithuania & 37,0 & 36,9 & $-0,1$ & 64,3 & 77,8 & 13,5 \\
\hline $\begin{array}{l}\text { Luxembour } \\
\mathrm{g}\end{array}$ & 27,9 & 33,2 & 5,3 & 70,7 & 72,1 & 1,4 \\
\hline Hungary & 24,1 & 28,7 & 4,6 & 59,9 & 74,4 & 14,5 \\
\hline Malta & 28,6 & 28,7 & 0,1 & 60,1 & 75,5 & 15,4 \\
\hline Netherland & 25,5 & 27,4 & 1,9 & 76,2 & 79,2 & 3 \\
\hline Austria & 28,3 & 26,8 & $-1,5$ & 73,9 & 76,2 & 2,3 \\
\hline Poland & 31,1 & 27,8 & $-3,3$ & 64,3 & 72,2 & 7,9 \\
\hline
\end{tabular}




\begin{tabular}{ccccccc} 
& 201 & 201 & $\begin{array}{c}\text { GINI } \\
\text { Evolution }\end{array}$ & $\begin{array}{c}201 \\
0\end{array}$ & $\begin{array}{c}201 \\
8\end{array}$ & $\begin{array}{c}\text { The employment } \\
\text { rate }\end{array}$ \\
\hline Portugal & 33,7 & 32,1 & $-1,6$ & 70,3 & 75,4 & 5,1 \\
Romania & 33,5 & 35,1 & 1,6 & 64,8 & 69,9 & 5,1 \\
Slovenia & 23,8 & 23,4 & $-0,4$ & 70,3 & 75,4 & 5,1 \\
Slovakia & 25,9 & 20,9 & $-5,0$ & 64,6 & 72,4 & 7,8 \\
Finland & 25,4 & 25,9 & 0,5 & 73 & 76 & 3,3 \\
Sweden & $\mathbf{2 5 , 5}$ & $\mathbf{2 7 , 0}$ & $\mathbf{1 , 5}$ & $\mathbf{7 8 , 1}$ & $\mathbf{8 2 , 4}$ & $\mathbf{4 , 3}$ \\
\hline
\end{tabular}

Source: Authors seletion based on Eurostat, 2018

With regard to Germany, there is an increase in the number of millionaires, along with the large-scale migration phenomenon in recent years. This aspect created the premises for the deepening of the disparities between the realized incomes, fact confirmed by the depreciation of the GINI index. "When the income produced in a country grows faster than the income received by households in that country, it means that the economy is not favorable to inclusion and that the prosperity gained is not shared by all households." [8]

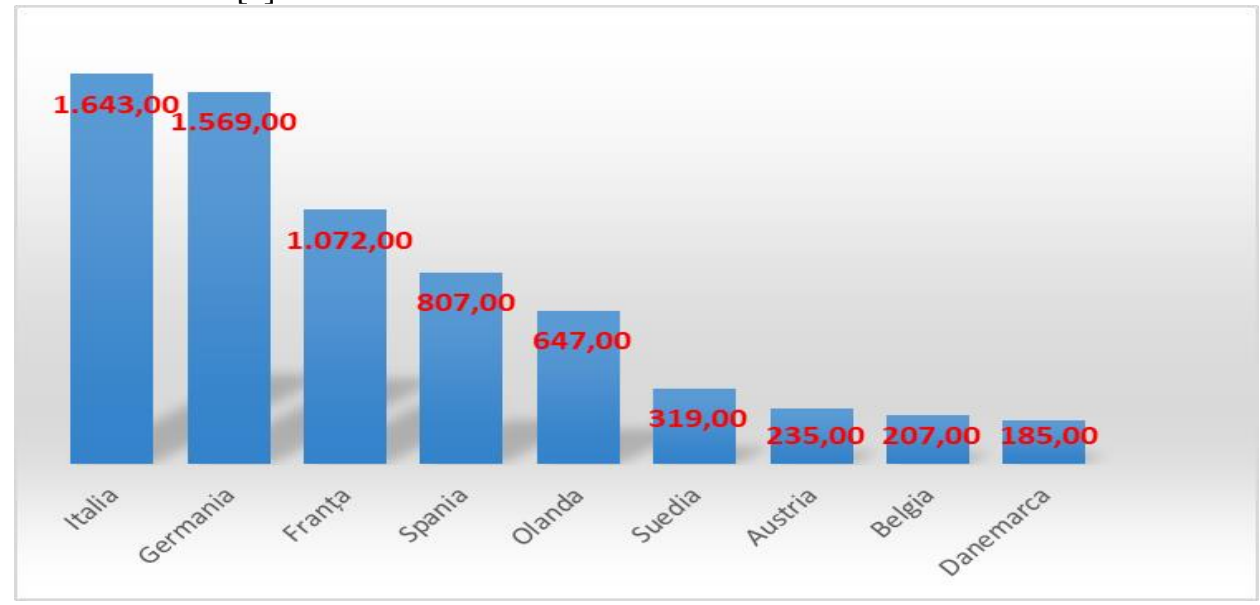

Figure 2. The milionaires number evolution in Europe, 2010-2019

Source: the authors processing based on data taken from the Global Wealth Report [6]

In order to reduce social inequalities, Member States come through a series of social policies that are aimed, in addition of increasing the number of jobs, a serie of social benefits for people at risk, vulnerable or with dependent children. Without these measures, the inequality rate would be much higher. It is noted that the EU average of social inequalities, before 
the application of the social measures by the state, is over $50 \%$, the lowest value being recorded by Slovakia (Table 4). After all social measures have been applied, the inequality rate is falling at European level by more than 20 percentage points. The measures are applied differently, from country to country, with the largest state interventions occurring in Sweden (over 30 percentage points) and the lowest being in Latvia.

Table 4. GINI Index before and after the social transfers UE27/UE28, 2018

Gini before

\begin{tabular}{lllll}
\multicolumn{5}{c}{$\begin{array}{l}\text { Gini before } \\
\text { the social }\end{array}$} \\
& $\begin{array}{l}\text { Gini before the } \\
\text { social transfers } \\
\text { (pensions } \\
\text { included) }\end{array}$ & $\begin{array}{l}\text { transfers } \\
\text { (pensions } \\
\text { excluded) }\end{array}$ & $\begin{array}{l}\text { Gini after } \\
\text { the social } \\
\text { transfers }\end{array}$ & $\begin{array}{l}\text { Gini } \\
\text { Differences }\end{array}$ \\
\hline UE28 & 51,1 & 35,9 & 30,8 & 20,3 \\
UE27 & 50,7 & 35,2 & 30,4 & 20,3 \\
Belgium & 46,9 & 32,7 & 25,7 & 21,2 \\
Bulgaria & 54,8 & 43,3 & 39,6 & 15,2 \\
Czechia & 42,4 & 27,3 & 24,0 & 18,4 \\
Denmark & 49,0 & 36,0 & 27,8 & 21,2 \\
Germany & 56,4 & 36,6 & 31,1 & 25,3 \\
Estonia & 44,1 & 34,1 & 30,6 & 13,5 \\
Irleland & 47,6 & 39,3 & 28,9 & 18,7 \\
Greece & 57,0 & 35,2 & 32,3 & 24,7 \\
Spain & 48,7 & 37,0 & 33,2 & 15,5 \\
France & 50,9 & 34,9 & 28,5 & 22,4 \\
Croatia & 49,8 & 33,8 & 29,7 & 20,1 \\
Italy & 48,5 & 35,7 & 33,4 & 15,1 \\
Cyprus & 47,6 & 34,0 & 29,1 & 18,5 \\
Latvia & 48,1 & 38,2 & 35,6 & 12,5 \\
Lithuania & 51,1 & 40,6 & 36,9 & 14,2 \\
Luxembourg & 51,9 & 38,1 & 33,2 & 18,7 \\
Hungary & 49,1 & 34,1 & 28,7 & 20,4 \\
Malta & 44,0 & 32,1 & 28,7 & 15,3 \\
Netherland & 46,6 & 32,7 & 27,4 & 19,2 \\
Austria & 46,3 & 32,9 & 26,8 & 19,5 \\
Poland & 46,3 & 32,7 & 27,8 & 18,5 \\
Portugal & 56,5 & 35,2 & 32,1 & 24,4 \\
Romania & $\mathbf{5 4 , 6}$ & $\mathbf{3 8 , 0}$ & $\mathbf{3 5 , 1}$ & $\mathbf{1 9 , 5}$ \\
& & & &
\end{tabular}




\begin{tabular}{lllll} 
& $\begin{array}{l}\text { Gini before } \\
\text { Ginial transfers } \\
\text { sociansions } \\
\text { (pensions } \\
\text { included) }\end{array}$ & $\begin{array}{l}\text { Gini after } \\
\text { the social } \\
\text { transfers } \\
\text { (pensions } \\
\text { excluded) }\end{array}$ & $\begin{array}{l}\text { Gine social } \\
\text { the } \\
\text { transfers }\end{array}$ & $\begin{array}{l}\text { Gini } \\
\text { Differences }\end{array}$ \\
\hline Slovenia & 42,5 & 28,8 & 23,4 & 19,1 \\
Slovakia & 37,2 & 24,3 & 20,9 & 16,3 \\
Finland & 48,8 & 34,4 & 25,9 & 22,9 \\
Sweden & 57,1 & 35,7 & 27,0 & 30,1 \\
UK & 53,7 & 40,4 & 33,5 & 20,2 \\
\hline
\end{tabular}

Source: Authors' processing based on Eurostat data

Although the employment rate, set as a target for 2020 under the Europe 2020 Strategy, has been exceeded by most countries in the European Union, inequalities have continued to deepen, even among the most developed countries in Europe. This indicates the inefficiency of the measures adopted by the Europe 2020 Strategy. The Strategy did not provide details on the level of deep poverty and whether the targets are sustainable in the long term. Reducing the number of people below the poverty line by increasing the minimum subsistence income, without taking into account (declining) purchasing power, makes it extremely difficult to maintain it above the poverty line.

For these reasons, without the complex assessment of the phenomenon, the increase of employment, the reduction of inequalities and poverty will only remain some indicators analyzed by extensive specialized studies, but without echo regarding the increase of the living standard of the population as a whole, and, in particular, of those living below the decent subsistence level.

Meanwhile, the European Union remains a mosaic of different inequalities that continue to deepen from year to year. According to some voices, it is not excluded that certain countries follow the example of the $\mathrm{UK}$, in order to follow a separate path with their own social policies.

As can be seen in Figure 3, Romania has reached its target of $70 \%$, in terms of employment rate, since the end of 2019, being constantly below the level of the European Union. 


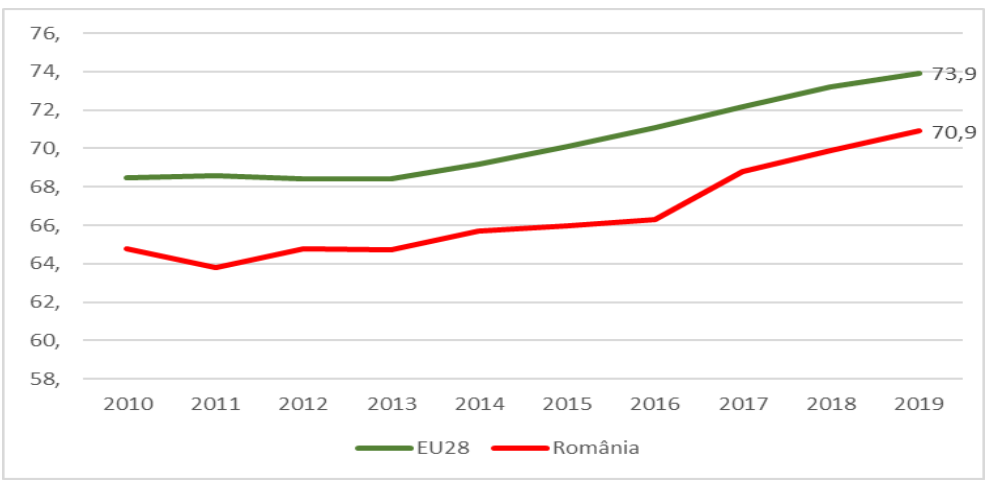

Figure 3. The evolution of the unemployment rate, 2010-2019 Source: authors' contribution based on INSSE data

Regarding the GINI Index, as it can be seen in the Figure 4, Romania is above the European Union average, reaching a maximum of 37.4 in 2015 and 35.1, at the end of 2018, increasing compared to 2010. This fact shows that the inequalities in Romania have deepened, which confirms the fact that a job does not guarantee a way out of poverty. If we look carefully at the data in Table 3, we notice that the inequality rate would have been $54.6 \%$ in Romania without the state intervention. If the state did not intervene with pensions and other social benefits, almost half of Romania's population would be below the relative poverty line (46.4\%).

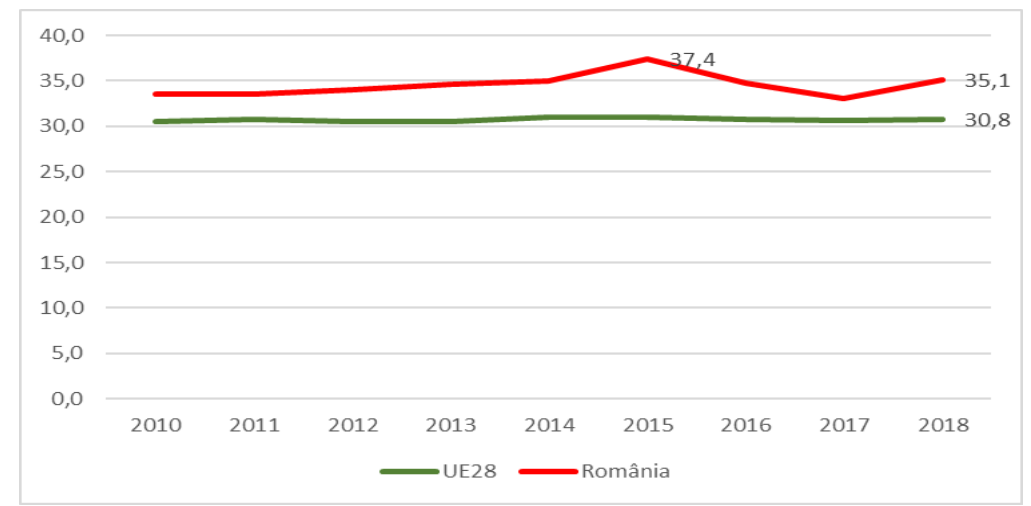

Figure 4. GINI Index evolution, 2010-2018

Source: authors' contribution based on INSSE data

Moreover, if we look at the evolution of the poverty rate after social transfers (Figure 5), it increased from $17 \%$ to $23.5 \%$ with a maximum 
reached in 2016 of $25.4 \%$. A decade after joining the European Union, in Romania, more than a quarter of the population continues to live in poverty.

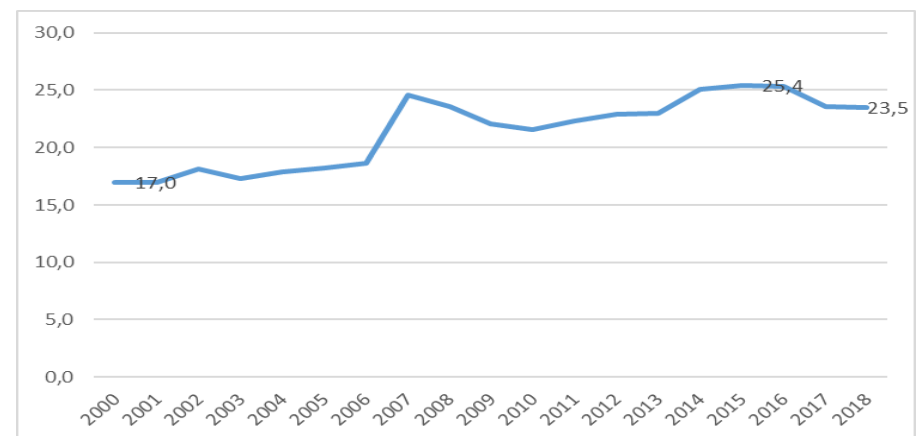

Figure 4. The poverty rate after the social transfers, 2000-2018

Source: authors' contribution based on INSSE data

In addition, it seems that a certain percentage of those who work continue to be poor. According to statistics, in the European Union 9.3\% of those who work are poor. Romania ranks 1 st in this respect, the poor but working population represents a share of $15 \%$ (Figure 6). Among the population that goes to work and still continues to be poor, according to INSSE statistics at the end of 2019, men (18.4\%) are more affected than women $(11.2 \%)$. It is really demotivating to go to work and continue to be poor. It is one of the reasons that discourages work and causes the population to either migrate to social assistance or to migrate to other countries, where the labor force is much better paid. Many workers face discouraging working environments, poverty-level wages, unsupportive management, insufficient social recognition, and weak career development [2]. In this way, Romania lost an important part of the skilled labor force which, due to the low salary, chose to go to other countries where incomes are higher.

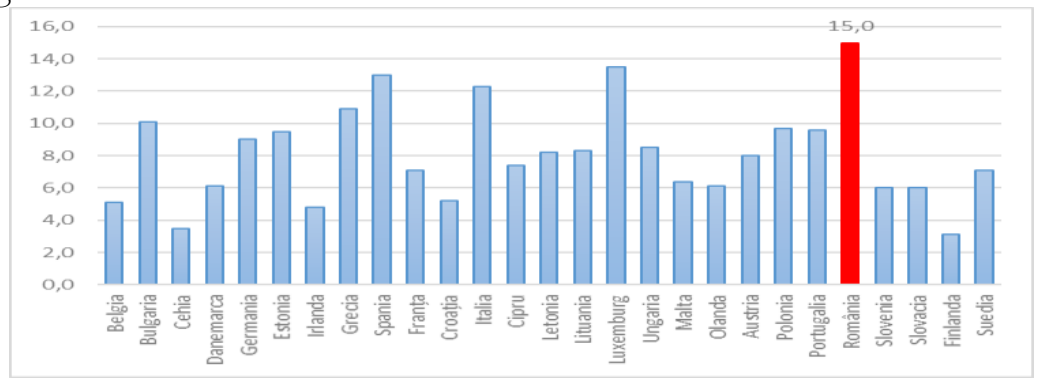

Figure 6. Employed population at risk of poverty, 2018.

Source: authors' contribution based on INSSE data 
How were the sustainable development objectives in Romania approached? It's hard to say. We are at the end of the Europe 2020 strategy and the goals of eradicating poverty and reducing inequality have not only not been achieved, but have been accentuated. On top of that, the recent pandemic is coming as an accelerator to the imminent collapse of human resources. According to studies during the crisis, the COVID19 pandemic will bring an impressive number of people back into poverty.

Even if the Romanian state has at its disposal an emergency support instrument (SURE) totaling 100 billion euros, this financial assistance involves loans that, even if they are in advantageous conditions, irreparably affect future generations.

In this context, the number of active employees decreased by over 900 thousand people in April 2020 and 340 thousand at the beginning of May. In addition, more than 1 million individual employment contracts have been suspended.[1]

If the employment rate has exceeded the target assumed for 2020, reaching the percentage of $70.9 \%$ at the end of 2019 , it is difficult to say how Romania will end the decade 2010-2020 in the conditions in which the social pillar was so serious affected. Such a shock was not taken into account, so social security and social assistance systems will play an important role in the next period.

\section{Discussions}

Where can the workforce that will be affected by the shock migrate? It is difficult to predict, in the context in which it is difficult to anticipate how countries' revenues will evolve in the future. Future migration is subject to great uncertainties, especially sustainable development. What can Romania do without sources of financing, with a weakened economic situation, in this economic context of maximum unpredictability?

\section{Conclusions}

Since joining the European Union, Romania has failed in all these years to raise the living standards of its citizens. Even though the number of those in employment has increased, one-fifth of them remain poor. This shows that the measures taken so far have not been effective or sustainable.

Development on sustainable principles requires a different approach. It will never be possible to improve the part if the whole is not treated. The problems of the social pillar, as part of the objectives on which sustainable development is based, will be solved only when the whole is seen. Until then, social disparities will continue to deepen. 
Results indicate that Romania is struggling with a social situation inferior to the Member States, without concrete measures to recover and counteract, social inequality will continue to deepen.

\section{References}

[1] Academia Română. Vulnerabilități ale pieței muncii [Internet]. Bucureşti. 2020. Available from: https://academiaromana.ro/SARS-CoV-2/doc/d04Vulnerabilitati_ale pietei muncii.pd

[2] Boboc C, Vasile V, Ghiță S. (2011) Migration of Physicians: Causes and Effects in CEE Countries. In: Zhou M, editor. Education and Management. ISAEBD. Communications in Computer and Information Science, vol 210. Berlin, Heidelberg: Springer; 2011. https://doi.org/10.1007/978-3-642-23065374 https://link.springer.com/chapter/10.1007/978-3-642-23065-3_74

[3] Bratu V. J.C. Juncker la București: Europa cu mai multe viteze există deja în tratate. Depinde de voi unde vă veți plasa [Internet]. 2017, 11-5. Available from: https:// cursdeguvernare.ro/j-c-juncker-la-bucuresti-europa-cu-maimulte-viteze-exista-deja-in-tratate-depinde-de-voi-unde-va-veti-plasa.html

[4] Commission of the European Communities (CEC). A Sustainable Europe for a Better World: A European Union Strategy for Sustainable Development. Brussels: CEC; 2001.

[5] Costea C, Popescu C, Taşnadi A. Criza e în noi. Bucureşti: Editura ASE; 2010. Available from:

https://books.google.ro/books?id=gfNrIStohnYC\&pg=PA186\&lpg=PA186 \&dq $=$ crizele + economice $+\% \mathrm{C} 3 \% \mathrm{AEn}+$ contextul + dezvolt $\% \mathrm{C} 4 \% 83$ rilor + dura bile\&source $=$ bl\&ots $=\mathrm{eZ} 4 \mathrm{Kq} 8 \mathrm{Dfl} 4 \& \mathrm{sig}=\mathrm{ACfU} 3 \mathrm{U} 25 \mathrm{GYpzadb} 2 \mathrm{JTGLEIUZC}$ CSd8NbniQ\&hl=en\&sa=X\&ved $=2$ ahUKEwid-K $1-$

O_pAhUtxosKHcf5CMAQ6AEwBnoECAkQAQ\#v $=$ onepage\&q $=$ crizele $\% 2$ Deconomice $\% 20 \% \mathrm{C} 3 \%$ AEn $\% 20$ contextul $\% 20$ dezvolt $\%$ C4 $\% 83$ rilor $\% 20$ durab $\underline{\text { ile\&f}=\text { false }}$

[6] Credit Suisse Research [Internet]. 2019. Available from: https://www.creditsuisse.com/about-us/en/reports-research/global-wealth-report.html

[7] European Sustainable Cities and Towns Charter (ESCTC). The Aalborg Charter. Aalborg, Denmark; 1994. Available from: http://ec.europa.eu/environment/urban/pdf/aalborg_charter.pdf.

[8] International Monetary Fund. World Economic Outlook, (2020) https://www.imf.org/en/Publications/WEO/Issues/2020/09/30/worldeconomic-outlook-october-2020 .

[9] Eurozone reform makes timid entry into EU debate, By Agence France-Presse, Map of European Union member states, highlighting the countries that use the euro courency, Grphic Jean Michel Cornu, Sebastien Casteran / AFP, 
[Internet]. 2017. Available from: https://www.ednh.news/eurozone-reformmakes-timid-entry-into-eu-debate/

[10] Schengen Visa Information, Map of the Schengen and EU Countries $_{s}$ [nternet]. 2020. Available from:

https://www.schengenvisainfo.com/eu-countries/ 